\title{
INTRAVENOUS COLCHICINE IN THE MANAGEMENT OF GOUTY ARTHRITIS*
}

\author{
BY \\ WALLACE GRAHAM and JAMES B. ROBERTS \\ From the Department of Medicine, University of Toronto, and the Medical Services, Sunnybrook Veterans' \\ Hospital and Toronto General Hospital, Canada
}

(RECEIVED FOR PUBLICATION OCTOBER 20, 1952;

Many ancient remedies have survived the passage of centuries and still find their place in the modern pharmacopoeia.: In most instances the secret of their action has come to light, and few, like colchicine, have defied the investigator for some 1,400 years.

A drug probably identical with colchicum was described in the Ebers Papyrus of 1500 B.C. (Smyth, 1949). Although chiefly known for its evacuant and cathartic properties, it was used for painful articular attacks by Jacques Psychriste (Jacobus Psychrestus), a physician of Constantinople in the time of the Emperor Leon the Great, A.D. 457-475 (Lits and others, 1938; Leopold, 1950). The first use of the drug for gouty arthritis is credited to Alexander of Tralles during the 6th century (Talbott, 1949). In the 12th century the Medical School of Salerno "knew that it helped arthritic gout and pellagra" (Leopold, 1950), and it was employed by the Arabian School in the 16th century against gout and rheumatism (Sollmann, 1948).

The plant from which the drug is derived was first named colchicum by the ancient Greeks because it flourished in Colchis in Asia Minor, but by others it has been called false saffron, bastard saffron, dogkiller, floating light, meadow saffron, and autumn crocus (Lits and others, 1938); it is a small plant resembling the tulip, and the alkaloid colchicine is obtained from the bulb, seed, or leaves.

However, the poisonous properties of colchicum must have disturbed the ancient physicians, and it gradually fell into disrepute until it was reintroduced by Baron Anton Von Storck in 1763 (Smyth, 1949). It is believed that Benjamin Franklin, himself a victim of gout, first brought colchicum to the United States after his sojourn in France about 1760 (Talbott, 1942).

According to Talbott (1949), isolation of the alkaloid was first achieved by Pelletier and Caventou (1820), but Lits and others (1938) give the credit to

* Read before the Canadian Rheumatism Association in June, 1952, at Banff, Alberta.
Houdé (1884; see also Laborde and Houdé, 1887). Colchicine has now replaced the wine and tincture of colchicum which are less stable, less reliable, and more nauseating than an equivalent dose of the alkaloid in tablet form.

Although the mode of action of colchicine is still unknown, its value in acute gouty arthritis is fully acknowledged, and its prophylactic role in the socalled "interval treatment" of gout has rightly received attention. More recently, the administration of ACTH has been effective in the acute attack, but colchicine has been administered concomitantly to prevent recurrence following withdrawal of the pituitary hormone, and despite the advent of hormone therapy, colchicine remains the most practical and effective drug in the treatment and prevention of acute gouty arthritis.

It is customary to administer colchicine orally in tablet form, the dosage being $0.5 \mathrm{mg}$. every hour, or $1.0 \mathrm{mg}$. every 2 hours, until the pain is relieved or gastro-intestinal symptoms supervene. If this timehonoured regimen is followed assiduously, the articular symptoms usually begin to subside in 12 to 24 hours, and, as a rule, the attack has largely abated in about 72 hours. In most patients, the effect of this oral therapy is dramatic, the toxic effect not too drastic, and the results are entirely satisfactory, at least in the early phases of gout. If gout has not previously been diagnosed and the patient has not tested the efficacy of colchicine, he is amazed at the prompt response, he looks with favour upon his physician, and the autumn crocus becomes, in his eyes, a fairer flower than the rarest tropical orchid.

However, to a lesser number of sufferers from gout the "colchicine cure" is looked upon with extreme disfavour, and the associated nausea, vomiting, and diarrhoea outweigh the benefits derived. A few develop extreme nausea after one or two milligrams orally, and prefer letting the arthritis take its course to suffering the misery of colchicine toxicity.

It seemed reasonable to suppose that intravenous 
administration of the drug might well have a less irritant effect on the gastro-intestinal tract. In June, 1949, a French preparation (Colchineos) for parenteral administration became available to us, and treatment of a series of patients was begun. At that time no references were found in the English literature to the use of colchicine intravenously in the treatment of gout, but a report by Coste and Durupt (1944) has now been discovered in the French literature. These workers appear to have been the first to recommend routine parenteral therapy; they treated seven patients with acute gouty arthritis and state that intravenous colchicine therapy should be substituted for oral administration in the majority of cases.

\section{Material and Methods}

In our series, 33 patients suffering from gouty arthritis have been treated with intravenous injections of colchicine. In several patients more than one attack has been so treated, and a number received more than one injection for a single attack. All the patients received $3 \mathrm{mg}$. crystalline colchicine in $3 \mathrm{ml}$. isotonic saline in a single dose. The oldest patient in the series was aged 80 and the youngest 35 . Several of the older patients had co-existing diseases: cholecystitis, chronic non-tuberculous chest disease, coronary artery disease with and without congestive failure, obliterative peripheral vascular disease, etc., but no untoward effects were observed. It should be noted that not all the patients received intravenous colchicine because of gastro-intestinal reactions to the oral preparation. Many tolerated the oral tablet well, but were included in the series in order to study the efficacy of intravenous administration.

\section{Results}

The response, as judged by symptomatic relief within one to six hours, was considered good in 24 patients, satisfactory in six, and poor in three.

In those showing a good response, dramatic relief from pain and throbbing in the affected joint occurred within 4 hours of the injection of $3 \mathrm{mg}$. colchicine. Several patients who were in considerable distress at the time of injection stated 3 hours later that they were free of pain while at rest. As a rule some active movement of the joint was possible at this stage. It is obviously difficult to ascertain the exact time of first symptomatic improvement, but a few patients insisted that they were better in $45 \mathrm{~min}$. The impression was gained that patients with multiple joint involvement improved more slowly, the definite improvement being more noticeable some 6 to 7 hours after the injection.

The response was described as satisfactory in six patients whose severe joint pain was relieved, though no more rapidly than one would expect in a good result from oral colchicine therapy.
The three patients who failed to respond to intravenous therapy had all previously failed to respond to adequate oral dosage.

(i) A 76-year-old male with polycythaemia vera, hyperuricaemia, and frequent attacks of gouty arthritis, consistently failed to respond to colchicine by mouth or vein.

(ii) The youngest patient in the series who, at 35 years of age, had advanced tophaceous gout.

(iii) A 67-year-old male with acute monarticular gout.

In thirty of the 33 patients, no other medication was given for a period of at least 12 hours following the initial injection of colchicine. If movement of the joint or weight-bearing was still painful, some patients were then given a second (or, later, a third) injection and others were placed on 1 to $4 \mathrm{mg}$. colchicine daily by mouth, depending upon their previous tolerance.

The nausea, vomiting, and diarrhoea, which are commonly seen after oral medication, were not observed in those who received a single injection of $3 \mathrm{mg}$. intravenously, but such effects occasionally followed repeated intravenous administration. One patient was given a second 3-mg. dose 6 hours after the first; vomiting and diarrhoea ensued. In another, cramps and diarrhoea followed a third 3-mg. injection given 48 hours after the second. A third patient was inadvertently given $8 \mathrm{mg}$. colchicine, $3 \mathrm{mg}$. intravenously and $5 \mathrm{mg}$. orally, during a 6-hour period; severe gastro-intestinal symptoms developed and lasted for 24 hours. However, most patients had no toxic symptoms, and those who did had usually been given both intravenous and oral therapy.

\section{Case Reports}

(1) Acute, monarticular, gouty arthritis.-A male, aged 61 , was given $3 \mathrm{mg}$. colchicine intravenously 36 hours after the onset of classical podagra. He had been unable to sleep the previous night and, when seen, was in acute distress and tired out. Two hours after the injection he was lying comfortably in bed. He said that the toe was "still a bit sore" but "nothing to bother about". There was still local tenderness on pressure over the joint, and 12 hours later he had no discomfort at rest but some on weight-bearing. A second 3-mg. dose was given and 24 hours later he could walk on tiptoe comfortably. There was no gastro-intestinal upset.

(2) Chronic, gouty arthritis with subacute, multiple joint involvement.-A male, aged 69, with a 16-year history of recurring gouty arthritis, had been bedridden without therapy for over 4 weeks before admission to hospital, having abandoned oral colchicine because of unusually severe diarrhoea. He had chronic gouty arthritis in his knees, feet, and ankles, and acute arthritis, migratory in character, affecting his toes, hands, and elbows. $2 \frac{1}{2} \mathrm{hrs}$ after $3 \mathrm{mg}$. intravenous colchicine, he had much less pain and could move the affected joints slightly. Eight hours 
after the injection he could scratch his forehead, which he had been unable to do for over four weeks. He expressed surprise that his joints were improving without other joints flaring up. A second dose was given 24 hours after the first, and he was placed on a maintenance dose of $1 \mathrm{mg}$. by mouth daily. His subsequent course was excellent and he maintained that he was "back on his feet" weeks earlier than usual, as his previous attacks had lasted approximately 4 months. There were none of the gastro-intestinal effects that had always accompanied oral administration.

(3) Acute polyarticular gouty arthritis.-A male, aged 53, with an 11-year history of acute gouty arthritis, had been confined to bed for 3 weeks before admission. He was febrile $\left(101^{\circ} \mathrm{F}\right.$.), in obvious distress, and appeared and felt systemically ill. He stated that he was unable to rest by day or night because of pain. Multiple tophi were observed. He was given $3 \mathrm{mg}$. colchicine intravenously and 5 hours later was relaxing comfortably in bed. He had his "first night's sleep in weeks", and 16 hours after the first injection he claimed that he felt " 100 per cent. better". There was some return of movement in all his affected joints except the right wrist. The 3-mg. dose was repeated, and, during the next 24 hours, his temperature became normal; the wrist remained unchanged but otherwise his acute attack appeared to be terminated. He had seven loose bowel movements. A third dose was given 48 hours after the second, in the hope that his wrist might improve. He was ambulatory by this time. After this third injection he had seventeen loose bowel movements in the next 18 hours, but the right wrist did not improve. On each of the next two days, he received $25 \mathrm{mg}$. ACTH intravenously during a 6-hour period with no rapid improvement in the right wrist, but during the next 7 days the wrist gradually improved. He left hospital 12 days after admission, feeling perfectly well, but he might have left on the fourth day except for the attempt to clear the stubborn arthritis of the right wrist.

\section{Toxic Effects}

In reviewing the treatment of 160 patients suffering from gouty arthritis, colchicine administered orally or intravenously has produced no untoward effects other than gastro-intestinal manifestations. However, there is no doubt that fatal poisoning may occur. In reported deaths, the total dose has varied considerably (Macleod and Phillips, 1947; Goodman and Gilman, 1941; Sollmann, 1948; Krantz and Carr, 1951).

(1) A patient died after $3 \mathrm{mg}$. colchicine, but he had also ingested about 240 grains of methyl salicylate in the space of one hour; he died 10 days later (Macleod and Phillips, 1947).

(2) Two patients died after taking 13 and $29 \mathrm{mg}$. respectively, but they suffered from inoperable carcinoma (Brown and Seed, 1945); the first received $13 \mathrm{mg}$. colchicine over a 4-day period and died on the 7th day, and the second received $29 \mathrm{mg}$. over 7 days and died on the 14th day. No distinctive gross changes were found at autopsy; microscopically there were numerous "colchi- $-\frac{0}{3}$ cine figures" (abnormal configurations or mitotic patterns $\square$ in the nuclei of cells, particularly in epithelial elements of parenchymatous organs and in lymphoid structures). $\Rightarrow$ It is stated later in this report, however, that similare changes are found not infrequently in the spleen or othero lymphoid structures in routine necropsy material irres-듬 pective of the cause of death.

It was felt that the chief cause of death in the two last patients was agranulocytosis and aplastic ${ }^{\infty}$ anaemia, and that this is "probably the greatest. single danger from colchicine administration". The $\overrightarrow{\vec{\omega}}$ authors concluded that colchicine was a dangerous $\omega$ drug and should be used with extreme care. In discussing five other deaths, Macleod and Phillips sug-.? gest that it is difficult to explain these cases "as other? than very rare examples of hypersensitivity to $\cdot \overrightarrow{-}$ colchicine",

The physiological and biochemical effects of col-윽 chicine in therapeutic dosage have apparentlyreceived little attention. A report dealing with the 3 response of certain allergic manifestations to an intravenous dose of $3 \mathrm{mg}$. appeared recently in the $\mathrm{J}_{-}^{\supset}$ French literature (Mugler, Wackenheim, and Grappe, $\vec{\oplus}$ 1951). The authors noted transient minor changes in. pulse, blood pressure and blood sugar levels, and, in several cases, a marked drop-exceeding 50 pers cent.-in circulating eosinophils. We have not been able to confirm this latter observation, and Robinson and others (1952) found no change in circulating ${ }_{\odot}^{\Phi}$ eosinophils in four gouty patients following the $\vec{F}$ administration of $2 \mathrm{mg}$. colchicine intravenously. $\frac{9}{3}$

The mode of action of colchicine in gouty crises? remains obscure, although attention has recentlyo been focused upon a possible effect on the so-called pituitary adrenal axis. Gutman and Yü (1950) feel⿳⺈ that the present evidence is by no means convincing. $\frac{0}{-}$ Wolfson (1949) reports that "while therapeutic doses. of colchicine do occasionally appear to release someo ACTH, the amounts are small, the effect is transitory, and the time of relapse may not coincide with? the time at which relief appears"'. Wolfson and others $>$ (1952) further report that, while colchicine producesㅡㅡ. metabolic changes in the normal adult, suggesting increased 11-oxy-steroid production, "it seems unlikely that this is a complete explanation for the $N$ action of colchicine in gout". Gutman (1950) has N recently expressed the view that "colchicine actso upon some enzyme system, presumably associatedo with the intermediary metabolism of purines".

Interest in colchicine has been stimulated by its $\stackrel{\infty}{?}$ effect upon the chromosomes of growing plant ando animal cells (Goodman and Gilman, 1941; Smith? and Fiddes, 1949). The effect on malignant growths? in the experimental animal (Lits and others, 1938) 
and on human cancer (Brown and Seed, 1945) has also been studied, but as yet no clinical application has resulted. Apart from the report of Mugler, Wackenheim, and Grappe (1951) regarding dramatic relief from pruritis and urticarial lesions, no clinical application of colchicine, other than in gouty arthritis, has been recognized.

\section{Summary}

The oral administration of colchicine remains the treatment of choice in the routine therapy of acute gouty arthritis, but the intravenous use of the drug deserves a much wider application where a rapid response is required and where severe gastrointestinal intolerance prohibits oral medication.

Colchicine was administered intravenously to 33 patients suffering from gouty arthritis. The majority experienced a rapid and dramatic relief from pain within 4 hours. No toxic reaction was observed after a single dose of $3 \mathrm{mg}$., but after repeated administration gastro-intestinal manifestations did occur occasionally.

Intravenous colchicine has proved to be a safe, rapid, and effective weapon for the treatment of acute gouty arthritis. The administration is simple and the effect in most cases no less prompt or complete than with intravenous ACTH, where the added hazard of withdrawal "flare-up" discounts the value.

The prophylactic and therapeutic value of the intravenous route for post-operative gout is obvious.

In one case intravenous colchicine was effective where oral administration of the drug had failed.

The mode of action of the drug, after some 1,400 years of use, remains obscure.

\section{REFERENCES}

Brown, W. O., and Seed, L. (1945). Amer. J. clin. Path., 15, 189.

Coste, F., and'Durupt, L. (1944). Bull. Soc. méd. Hôp. Paris, 60, 284.

Goodman, L., and Gilman, A. (1941). "The Pharmacological Basis of Therapeutics," p. 239. Macmillan, New York.

Gutman, A. B. (1950). Amer. J. Med., 9, 799.

, and Yü, T. F. (1950). Ibid., 9, 24.

Houdé, A. (1884). C. R. Soc. Biol., $8 \mathrm{ser}, 1,218$.

Krantz, J. C., and Carr, C. J. (1951). "Pharmacologic Principles of Medical Practice," 2nd ed., p. 981. Williams and Wilkins, Baltimore.

Laborde, J. V., and Houdé, A. (1887). "Le colchique et la colchicine" Steinheil, Paris.

Leopold, H. N. (1950). Tex. St. J. Med., 46, 710.

Lits, F. J., Kirschbaum, A., and Strong, L. C. (1938). Amer. J. Cancer, 34, 196.

Macleod, J. G., and Phillips, L. (1947). Annals of the Rheumatic Diseases, 6, 224.

Mugler, A., Wackenheim, A., and Grappe, J. (1951). Bull. Soc. méd. Hôp. Paris, 67, 821.

Pelletier and Caventou (1820). Ann. Chim. Phys., 14, 69

Robinson, W. D., Conn, J. W., Block, W. D., Louis, L. H., and Katz, J. (1952). In American Rheumatism Association: "Rheumatic Diseases". Based on the Proceedings of the Seventh International Congress on Rheumatic Diseases, p. 252. Saunders, Philadelphia.

Smith, S., and Fiddes, F. S. (1949). "Forensic Medicine," 9th ed., p. 549. Churchill, London.

Smyth, C. J. (1949). In Comroe's "Arthritis and Allied Conditions", ed. J. L. Hollander, 4th ed., p. 720. Lea and Febiger, Philadelphia.
Sollmann, T. H: (1948). "A Manual of Pharmacology and Its Applications to Therapeutics and Toxicology," 7th ed., p. 483. Saunders, Philadelphia.

Talbott, J. H. (1942). Bull. N.Y. Acad. Med., 18, 318.

- (1949). In "Oxford Medicine", ed. H. A. Christian, vol. 4, p. 81 Oxford University Press, New York.

Wolfson, W. Q., Cohn, C., and Levine, R. (1949). J. Lab. clin. Med., 34, 1766.

H. S. (1952). In American Rheumatism Association: "Rheumatic Diseases", p. 257. Saunders, Philadelphia.

Colchicine intraveineuse dans le traitement de l'arthrite goutteuse

RÉSUMÉ

La colchicine par voie buccale demeure le traitement classique de l'arthrite goutteuse aiguë, mais son application intraveineuse mérite un champ d'application plus étendu lorsqu'on veut obtenir un effet plus rapide et quand l'intolérance gastro-intestinale contre-indique la médication buccale.

La colchicine fut administrée par voie intraveineuse à 33 malades atteints d'arthrite goutteuse. La plupart d'eux éprouvèrent un soulagement rapide et dramatique de leur douleur en moins de 4 heures. On n'observa aucune réaction toxique après une seule dose de $3 \mathrm{mg}$., mais quelquefois l'administration répétée fut suivie de troubles gastro-intestinaux.

La colchicine intraveineuse s'est montrée inoffensive, rapide et efficace dans le traitement de l'arthrite goutteuse aiguë. Son administration est simple et son effet dans la plupart des cas n'est pas moins rapide ni moins complet que celui de l'ACTH par voie intraveineuse; de plus, contrairement à l'ACTH, on ne court pas le danger d'exacerbation après l'interruption du traitement.

La valeur prophylactique et thérapeutique de la voie intraveineuse dans la goutte post-opératoire est évidente.

Dans un cas la colchicine fut efficace par voie intraveineuse quand la voie buccale avait échoué.

Le mode d'action de ce médicament, après 1,400 années de son emploi, demeure obscure.

Colchicina endovenosa en el tratamiento de la artritis gotosa Sumario

La colchicina por vía oral sigue siendo el tratamiento rutinario de la artritis gotosa aguda, pero su introducción endovenosa merece mayor consideración cuando se desea obtener un efecto más rápido y cuando la vía oral está contraindicada por causa de intolerancia gastrointestinal.

La colchicina fué administrada por vía endovenosa a 33 enfermos con artritis gotosa. La mayoría de ellos acusó un alivio rápido y dramático del dolor dentro de 4 horas. Después de una dosis de $3 \mathrm{mg}$. no se observaron reacciones tóxicas, pero a veces la administración repetida produjo disturbios gastro-intestinales.

La colchicina endovenosa mostrose inofensiva, rápida $\mathrm{y}$ eficaz en el tratamiento de la artritis gotosa aguda. Su administración es sencilla y su efecto en la mayoría de los casos no es menos rápido ni completo que él de la ACTH por vía endovenosa; además no hay peligro de exacerbación al cesar el tratamiento.

En valor profiláctico y terapéutico de la vía endovenosa en la gota post-operativa parece obvio.

La colchicina fué efficaz por vía endovenosa en un caso en que la vía oral hábía fracasado.

El modo de acción de este medicamento, después de 1,400 años de su empleo, queda oscuro. 